\title{
CARBON STOCK EVALUATION FROM TOPSOIL OF FOREST STANDS IN NE ITALY
}

\author{
V. Faggian, C. Bini, and D. M. Zilioli \\ Department of Environmental Sciences, University of Venice, Italy
}

Gas emissions from anthropic activities, particularly CO2, are responsible for global warming. Soil is a major carbon sink on a planetary level, thereby contributing to mitigate greenhouse effect. In the present work, the objectives were: 1) to evaluate the topsoil carbon stock of different forest stands in NE Italy, and 2) to outline the relationships among humus forms, soil organic matter dynamics, and actual carbon stock under different vegetation coverage, with reference to climate change. Five forest stands and the related topsoils, were selected in the Dolomites area. The humus forms were examined in the field and samples were carried to the lab for further physical-chemical analyses. The carbon stock for each soil was calculated by means of pedotransfer functions. The less developed humus forms, as the Dysmull and the Hemimoder, presented the highest carbon storage capacity (168 t/y and 129 t/y), followed by Lithoamphimus (123 t/y) and Eu-amphimus (96 t/y), and by Oligomull (86 t/y). Organic horizons proved to recover $36 \%$ of the total carbon stocked along the soil profile, and this points to humus layers as a fundamental tool in carbon stock evaluation. Positive correlations between elevation, humus forms and soil carbon pools were found.

KEY WORDS: humus forms, forest stands, SOC, pedotransfer functions, carbon stock

\section{INTRODUCTION}

Soils represent one of the most important carbon sink on a global scale, and play a key role in global $\mathrm{C}$ cycle, which in turn is one of the key processes governing climate change (Penne et al. 2010). According to Batjes (1996), the amount of organic carbon sequestered by the soil (SOC) is larger than the pool of both biosphere $(610 \mathrm{Pg} \mathrm{C})$ and atmosphere (750 Pg C), totaling ca $1500 \mathrm{Pg} \mathrm{C}$, approximately one-quarter of the total amount produced by human activities. Forest soils are particularly enriched in organic matter (SOM) with respect to agricultural soils, and represent a fundamental sink for atmospheric $\mathrm{CO}_{2}$ sequestration; however, they can be also a source of greenhouse gases, as $\mathrm{CO}_{2}$ and $\mathrm{CH}_{4}$, depending on the processes which govern SOM accumulation and stabilization, or losses (Zimmermann et al. 2007; Lal 2009). Yet, changes in the amount of SOM pools and in its turnover rate may potentially alter the atmospheric $\mathrm{CO}_{2}$ concentration, and consequently the global climate (IPCC 2001). The capacity of soils to accumulate and stabilize organic carbon has received great attention in recent years (Lützow et al. 2006, 2008; Spielvogel

Address correspondence to V. Faggian, Department of Environmental Sciences, University of Venice, 2137 Dorsoduro, Venezia 30123, Italy. E-mail: vale_faggi@libero.it 
et al. 2009; Gruneberg et al. 2010; Llorente et al. 2010). The long-term storage of C in soil ecosystems is determined by the balance between the rate of incorporation of new organic matter $(\mathrm{OM})$ in soil and the decomposition of SOM. Variations in soil OC stocks are related to specific soil properties (e.g. $\mathrm{pH}$, texture), to the complexity of physical, chemical and biological processes (e.g., burrowing, microbial activity) that influence $\mathrm{C}$ cycling in the soil, and to a number of natural factors (e.g., parent material, topography, vegetation, climate), and human-induced factors, such as land use, management intensity(Mou et al. 2005; Somaratne et al. 2005; Lützow et al. 2006; Gruneberg et al. 2010).

Early studies on SOC (Schnitzer 1986; Stevenson 1994) were aimed at highlighting its key role in playing different ecological functions (e.g., chemical fertility, structural stability, soil quality, agroecosystem productivity); moreover, SOC is essential for evaluating soil and ecosystem functions (Smith et al. 2000; Lopez et al. 2008), for understanding soil carbon sequestration processes (Venteris et al. 2004), and for estimating OC stocks at a national or global scale (Dixonet al. 1994; Batjes 1996). The SOC content, therefore, results an effective environmental indicator, being related to many aspects of agro-forest productivity, ecosystem sustainability and carbon stock. More recently, attention has been focused on the ability of soil to storage and accumulate OC along the soil profile under various land uses (Lal 2005; Mikhailova et al. 2006; Cerli et al. 2009; Schulze et al. 2009), in order to develop strategies of soil management so as to increase the SOC storage and reduce the atmospheric $\mathrm{CO}_{2}$.

To estimate accurately the organic carbon (OC) stocks in soils is difficult because the relative importance of natural and human-induced factors, and the resulting spatial pattern of OC stocks, are still poorly understood. Until now, there are only few studies where estimates of OC stocks have been calculated based on a high number of direct measurements (Perruchoud et al. 2000; Prichard et al. 2000; Banfield et al. 2002; Kulmatiski et al. 2004; Garlato et al. 2009a,b; Andreetta et al. 2010; Gruneberg et al. 2010). Other studies have examined SOC spatial variability from a relatively small number of representative soil profiles at the plot scale in a range of natural and semi-natural environments (Schöning et al. 2006; Don et al. 2007), and sources of uncertainty affecting soil organic carbon estimates have been recorded by Galbraith et al. (2003) in Northern New York.

In this paper attention is focused on organic C storage in surface layer $(0-20 \mathrm{~cm})$ of forest soils under different forest coverage. In particular, we investigated the sequence and nature of surface organic $(\mathrm{O}, \mathrm{H})$ and organo-mineral $(\mathrm{A})$ horizons, usually defined as the forest humus (Zanella et al. 2009), i.e., that part of SOM which derives from the degradation and decomposition of animal and plant remains (Zanella et al. 2001). The alteration mechanisms and the chemical structure of humic substances are not completely known, but they have a relevant resistance to chemical-physical degradation, higher than the primary compounds (Piccolo 1996; Wuddivira et al. 2007; Dou et al. 2008). Recent advances in SOM dynamics suggest a link between the humus forms and SOC stabilization (Andreetta et al. 2010); mean residence time and turnover are generally related to the humus forms, and proved much lower in organic than in organo-mineral horizons of forest soils (Schulze et al. 2009), which could represent a significant sink of refractory carbon. However, the relationships between humus forms, SOC stability, and soil carbon stock are not completely known.

Based on this statement, the objectives of this work were: (1) to characterize the humus forms under different forest stands in Alpine environment, (2) to estimate the soil carbon stock for each kind of humus forms, (3) to outline the relationships among 
humus forms, soil organic matter dynamics, and soil carbon stockwith reference to climate change.

\section{MATERIALS AND METHODS}

\section{Study Area}

The studied area is located between Cortina D'Ampezzo and Borca di Cadore municipalities, in the Veneto Region (Northern Italy). The geological substrate of the whole area is constituted mostly of calcareous rocks (dolostone and limestone dating back to the Middle Triassic - Lower Cretaceous period), which form soaring cliffs and detritic material disseminated along deep slopes (Bosellini 1996). The climate of the area is influenced by both orography (the highest peaks have an altitude over $3.200 \mathrm{~m}$ a.s.l.), and continentality. The continental character is more evident in the Cortina territory (NW of the studied area), where rainfall ( $\mathrm{maP}=1238$ ) is relevant during summer and minimum in winter, while in Borca di Cadore (SE) rainfall distribution is more homogeneous during all the year (Table 1); hence, it may be inferred that there exists a climatic gradient from NW to SE, which is pointed out also in the phytoclimatic subdivision proposed by Del Favero and Lasen (1993). Based on monthly thermo-pluviometric data from three different meteorological stations within the investigated area (P.so Falzarego, $2100 \mathrm{~m}$ a.s.l.; Podestagno, 1314 $\mathrm{m}$ a.s.l.; Valle di Cadore, $856 \mathrm{~m}$ a.s.1.), the soil water balance was calculated following the Thornthwaite method (quoted in Andreis et al. 2003). Soil moisture regime results perudic at higher altitude $(>1600 \mathrm{~m})$ and udic at low altitude. The soil temperature regime is frigid for all the soils considered, being maT within the range $0-8^{\circ} \mathrm{C}$, with a difference $>6^{\circ} \mathrm{C}$ between summer and winter (Table 1).

The forest coverage of the investigated area is influenced by the environmental characteristics (altitude, exposure, microtopography, lithology). According to Pignatti (1981), the Ampezzo Basin (North-West) is included in the Internal Dolomites bioclimatic zone, while the Boite River Valley (South-East) is included in the External Dolomites bioclimatic zone. Del Favero and Lasen (1993), in their framework on the Veneto vegetation, distinguish in the investigated area five different vegetal associations: Picetum (Typical Subalpine Spruce), Pinetum (Endalpic Scots Pine), Cembretum (Typical Swiss Stone Pine), Laricetum (Typical Larch), and Ostryetum (Hop Hornbeam).

\section{Sampling Sites}

For a preliminary selection of the sampling stations, the Geological Map (1:100.000) and the Forest Vegetation Map of Cortina d'Ampezzo (Pignatti 1981) were used. We

Table 1 Selected thermo-pluviometric data from three different meteorological stations within the investigated area: elevation, mean annual precipitation (maP), mean, maximum (MAX) and minimum (MIN) air temperature, and potential evapotranspiration (PET)

\begin{tabular}{lcccccr}
\hline \multirow{2}{*}{$\begin{array}{l}\text { Meteorological } \\
\text { Station }\end{array}$} & $\begin{array}{c}\text { Elevation } \\
(\mathrm{m})\end{array}$ & $\begin{array}{c}\mathrm{maP} \\
(\mathrm{mm})\end{array}$ & MIN & MAX & Mean & $\begin{array}{r}\text { PET } \\
(\mathrm{mm})\end{array}$ \\
\hline P.so Falzarego & 2100 & 1172 & -5.0 & 10.6 & 2.1 & 33.7 \\
Podestagno (Cortina) & 1314 & 1238 & -3.6 & 14.3 & 5.1 & 41.1 \\
Valle di Cadore & 856 & 1123 & -1.0 & 17.1 & 8.0 & 50.1 \\
\hline
\end{tabular}


selected five sites with similar geological and morphological features, but reflecting differences in elevation, climate, and land cover, and considered by Del Favero and Lasen (1993) as representative forest stands of the studied area: Subalpine Spruce (Picea abies (L.) Karsten) at site H1 (elevation $1700 \mathrm{~m}$ ), Endalpic Scots Pine (Pinus sylvestris L.) at site H2 (elevation 1325 m), Swiss Stone Pine (Pinus cembra L.) at site H3 (elevation 1800 m), Larch (Larix decidua Mill.) at site H4 (elevation 1660 m), and European Hop Hornbeam (Ostrya carpinifolia Scop.) at site H5 (elevation 975 m). The identification of soils under the five forest stands was carried out by comparing data collected during the sampling campaign and the information contained in the Soil Map of Cortina D'Ampezzo (Zilioli 2007).

At each selected site, soil pits were excavated for pedogenetic characterization of the soil. Full information about standard pedological analyses is available from the authors. The soils were classified according to the criteria of the last edition of Keys to Soil Taxonomy (USDA 2010) and have been found to belong to three orders. In particular, Entisols (Lithic Udorthents) were found in the Larch stand (site $\mathrm{H} 4$ ), in a portion of land with parent material consisting of mostly calcareous debris. Inceptisols (Humic Lithic Eutrudepts) were found under the Subalpine Spruce stand (site H1), on limestone substrate and with quite pronounced slope. Mollisols (Lithic Haprendolls) were identified under Endalpic Scots Pine stand (site H2), Swiss Stone Pine stand (site H3), and European Hop Hornbeam stand (site H5), with mainly calcareous parent material.

\section{Field and Laboratory Methods}

At five points around each soil pit we sampled the surface soil horizons ( $\mathrm{O}$ and A). A detailed macroscopic description of topsoil was carried out with the help of a field description sheet produced by Green, Trowbridge, and Klinka (1993) and adapted by Calabrese et al. (1996). The morphological description of the organic (OF, OH) and mineral (A, AC) horizons allowed to identify the humus forms according to the French classification (Référentiel Pèdologique - AFES 2009). The following humus forms have been identified: Dysmull at site H1 under Spruce, Tangel, or Lithoamphimus at site H2 under the Scots Pine, Hemimoder at site H3 under the Swiss Pine, Oligomull at site H4 under Larch, and Eu-Amphimus at site H5 under the European Hop Hornbeam.

Topsoil samples were subdivided into horizons immediately after sampling; each horizon was air-dried over one week, then crushed and finally subsamples were sieved at $0.5 \mathrm{~mm}$ and $2 \mathrm{~mm}$ to separate stones, coarse roots, and soil material. Soil samples $<0.5 \mathrm{~mm}$ in size were analyzed to determine total organic carbon (TOC), total extractable carbon (TEC), humic carbon (HC), and total Kjeldahl nitrogen (TKN), while soil material $<2$ $\mathrm{mm}$ was analyzed for $\mathrm{pH}$ and $\mathrm{LOI}_{550}$ (loss on ignition at $550^{\circ} \mathrm{C}$; see Table 2). All the analyses were carried out according to the Italian Legislation Acts (DM 13/09/1999-GU $\mathrm{N}^{\circ} 248$ 21/10/1999) except for $\mathrm{LOI}_{550}$, for which the procedure described by De Vos et al. (2005) was followed. Soil $\mathrm{pH}$ was determined potent biometrically in a suspension 1:10 soil-water and soil-0.01 M KCl solution. TOC, TEC, and $\mathrm{HC}$ were determined by the standard Springer-Klee method (Springer and Klee 1954); the procedure was applied directly to the soil fraction $<0.5 \mathrm{~mm}$ for TOC determination, while TEC and HC were determined respectively on the liquid phase and on the solid phase (SPE) extracted with a $0.1 \mathrm{M} \mathrm{Na}_{4} \mathrm{P}_{2} \mathrm{O}_{7} \times 10 \mathrm{H}_{2} \mathrm{O}+\mathrm{NaOH}$ solution. TKN was determined by distillation according to the Kjeldahl method (reported in DM 13/09/1999-GU N 248 21/10/1999). LOI 550 was determined according to De Vos et al. (2005), keeping $3 \mathrm{~g}$ of dried sample at $550^{\circ} \mathrm{C}$ for 


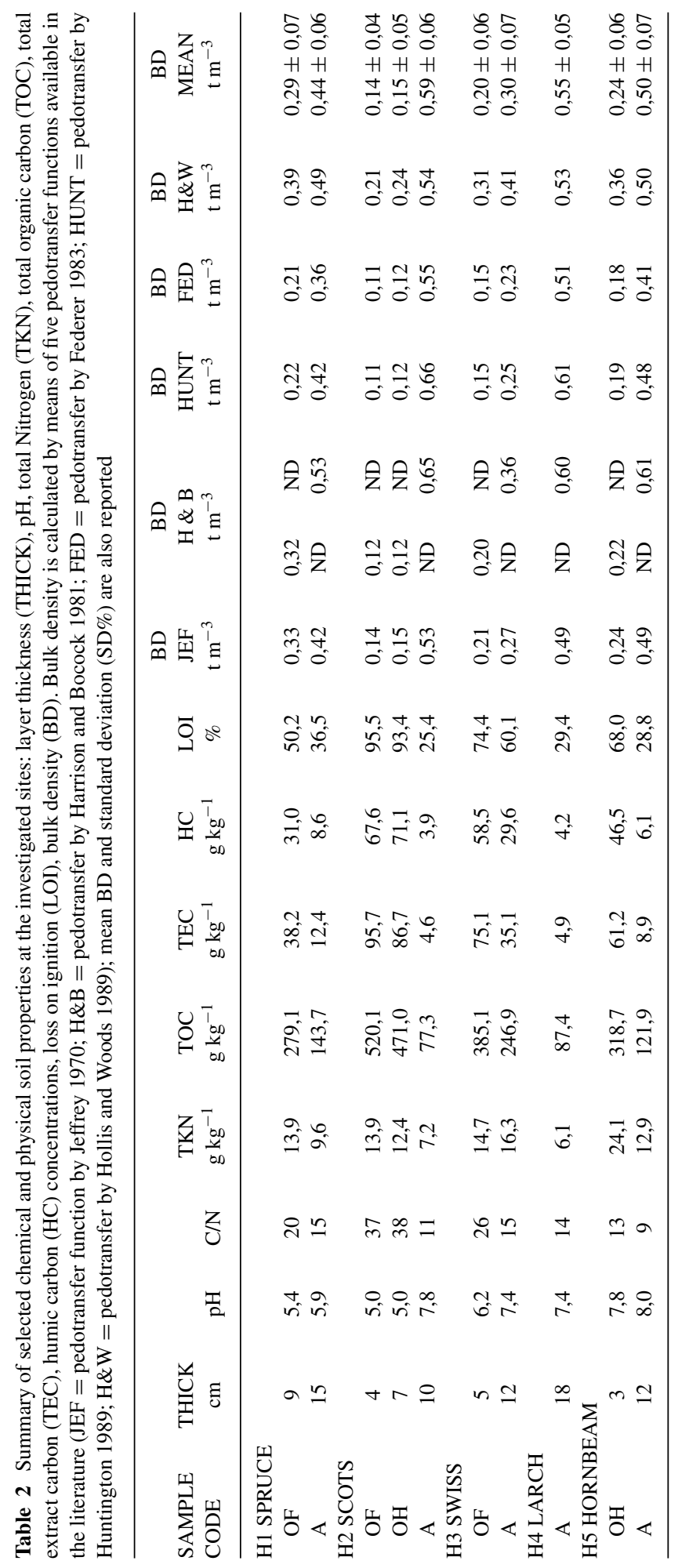


three hours. The OM content is estimated through weight loss; since at that temperature there is not carbonate breakdown, inorganic carbon contribution is not included in OM calculation.

\section{Soil Bulk Density and Soil Organic Carbon Stock Estimates}

Soil organic C stock (SOCs) for each horizon was calculated applying the following equation (Schwager and Mikhailova 2002):

$$
\text { SOCs }=\sum_{\mathrm{n}=1}^{\mathrm{K}}(\mathrm{C} \times \rho \times \mathrm{T} \times(1-\delta) \times 10)
$$

where SOCs is the stock of organic carbon per unit area $\left(\mathrm{t} \mathrm{ha}^{-1}\right), \mathrm{C}$ is the concentration of organic $\mathrm{C}$ in the $\leq 0,5 \mathrm{~mm}$ soil fraction $\left(\mathrm{g} \mathrm{kg}^{-1}\right), \rho$ is the soil bulk density $\left(\mathrm{t} \mathrm{m}^{-3}\right)$, $\mathrm{T}$ is the layer thickness $(\mathrm{m})$ and $\delta$ is the proportion of coarse material ( $>2 \mathrm{~mm}$ in size). To apply the above equation, the bulk density (BD) value is required, a parameter that is difficult to calculate directly from humus forest soils samples (Hedde et al. 2007; Schulp et al. 2008), and is frequently estimated by means of pedotransfer functions (Garlato et al. 2009b; Goidts et al. 2009). Yet, some studies (ARPAV 2006; Garlato et al. 2009a) have focused on uncertainties in SOC stock assessment and have demonstrated the importance of directly measuring the soil BD, while indirect estimates based on pedotransfer functions can lead to errors from $9 \%$ up to $36 \%$ of the SOCs (Goidts et al. 2009). On the other hand, Schulp et al. (2008) have demonstrated that there are several difficulties in measuring BD in forest soils, due to the extreme variability of the humus thickness, the presence of stones and roots, the risk of compaction during sampling. For this study, five pedotransfer functions available in the literature (see De Vos et al. 2005, and references therein) were selected according to their predictive capability, and to the availability of the predictor variables requested, as reported by De Vos et al. (2005).

\section{RESULTS}

\section{Soil Chemical-Physical Characteristics}

The five topsoils included both organic (OF, $\mathrm{OH})$ and organo-mineral (A) horizons. Data concerning topsoil chemical-physical characteristics are reported in Table 2. Topsoil thickness varies from $24 \mathrm{~cm}$ at site 1 to $15 \mathrm{~cm}$ at site 5, depending on topography, parent material, and land cover. The $\mathrm{pH}$ ranges from subacidic (5.0 at site 2 under Scots Pine) to subalkaline ( 8.0 at site 5 under Hornbeam).

Total Nitrogen (TKN) ranges between $6,1 \mathrm{~g} \mathrm{~kg}^{-1}$ in the A horizon at site $\mathrm{H} 4$, to $24,1 \mathrm{~g} \mathrm{~kg}^{-1}$ in the $\mathrm{OH}$ horizon at site $\mathrm{H} 5$, while total organic Carbon (TOC) ranges between $77.3 \mathrm{gkg}^{-1}$ to $520.1 \mathrm{gkg}^{-1}$, the lowest values being those of the A horizons, whereas the highest are those of the OF horizons. The resulting $\mathrm{C} / \mathrm{N}$ ratios are higher in the $\mathrm{OF}-\mathrm{OH}$ horizons than in the A horizons, suggesting a higher mineralization rate to occur in the latter. The broadleaf forest floor at site 5 proved the most mineralized, and the Scots Pine stand at site 2 the least one. The total extractable carbon (TEC) is higher in organic horizons in comparison to the A horizons; at site 2, TEC presents the highest amount $\left(182.4 \mathrm{gkg}^{-1}\right)$, while the least was recorded at site 1 under spruce $\left(38.2 \mathrm{gkg}^{-1}\right)$. Humic carbon (HC) 
amounts present similar distribution than TEC, with the least values in the A horizons, as well as loss on ignition (LOI).

We calculated the bulk density (BD) of topsoils by means of PTFs available in the literature (De Vos et al. 2005). The related values are reported in Table 2 together with mean value and standard deviation (SD). There is good agreement among the different PTFs values, with slight differences, for both the organic and organo-mineral horizons, the least BD value being that of the OF horizon at site $2\left(0.14 \mathrm{tm}^{-3}\right)$, and the highest that of the A horizon at site $2\left(0.59 \mathrm{tm}^{-3}\right)$, as expected.

\section{Soil Carbon Stock Calculation}

The investigated sites present typical features of alpine soils developed from calcareous materials: little horizonation, humus accumulation, limited soil depth, large amount of skeleton, subalkaline reaction, loamy texture (Zilioli and Bini 2009). One important feature is the relative proportion of coarse fragments ( $>2 \mathrm{~mm}$ in size) per unit volume, that may influence the carbon stock in the whole profile (Corti et al. 2002). Another important feature to consider in evaluating OC stock is the variability of soil thickness, which in turn is a function of topography, vegetation cover and soil development. In order to take into account these two fundamental aspects in calculating the SOC stock of the investigated sites by the equation (1), we have considered four different scenarios, two related to the actual soil thickness (including and excluding coarse fragments), and two related to a potential scenario where a soil thickness of $10 \mathrm{~cm}$ is considered (including and excluding coarse fragments, as in the previous two scenarios).

The SOC stock calculation in the real scenario, both including and excluding the coarse fraction, is reported in Figure 1 (top). It allows evaluating the current soil capacity to block carbon in the organic form in the investigated profiles. Poorly evolved humus forms as Hemimoder (H3), and thick humus as Dysmull (H1), store more carbon, although this depends marginally on the type of humus, since in this scenario horizons thickness and the amount of coarse material (roots and stones), play a key role. In fact, comparing the average values of carbon stored by different humus forms and the horizon thickness (Figure 1), at site $\mathrm{H} 2$ a moderately evolved humus form (Lithoamphimus) stores $100 \mathrm{tha}^{-1}$ on average, and the Dysmull at site $\mathrm{H} 1$ stores 151 tha $^{-1}$ on average.

SOCs values found at the investigated sites are consistent with those reported by Garlato et al. (2009b). In fact, in the present study a SOCs average of $7 \mathrm{t} \mathrm{ha}^{-1} \mathrm{~cm}^{-1}$ was found, which is consistent with $9 \mathrm{t} \mathrm{ha}^{-1} \mathrm{~cm}^{-1}$ found by the previous authors for organic horizons in the Veneto region. However, they estimated the bulk density (BD) by the Hollis and Wood (1989) pedotransfer function, which is known to be influenced by an overestimation error (Garlato et al. 2009a).

The presence of the coarse fraction in the profile reduces the OC storage capacity, since the available volume of fine earth $(<2 \mathrm{~mm})$ is reduced; therefore, in order to investigate how much the coarse fraction influences the SOCs estimate, we calculated the SOCs on the real horizons thickness but excluding the coarse fraction (Figure 1, bottom).

The comparison between carbon stocks considering the coarse material, or excluding it, shows its importance in the assessment of the humus capability to sequester carbon (Figure 1); in fact, the coarse material decreases the average $\mathrm{C}$ stock about $20 \%$ at site $\mathrm{H} 2$, around $30 \%$ at site $\mathrm{H} 5$, and over $40 \%$ at site $\mathrm{H} 4$, with respect to the sole fine material. Yet, the general trend concerning all the examined samples is shown in the 2nd scenario (Figure 1, bottom); although in terms of $\mathrm{C}$ tons per hectare there are differences between 


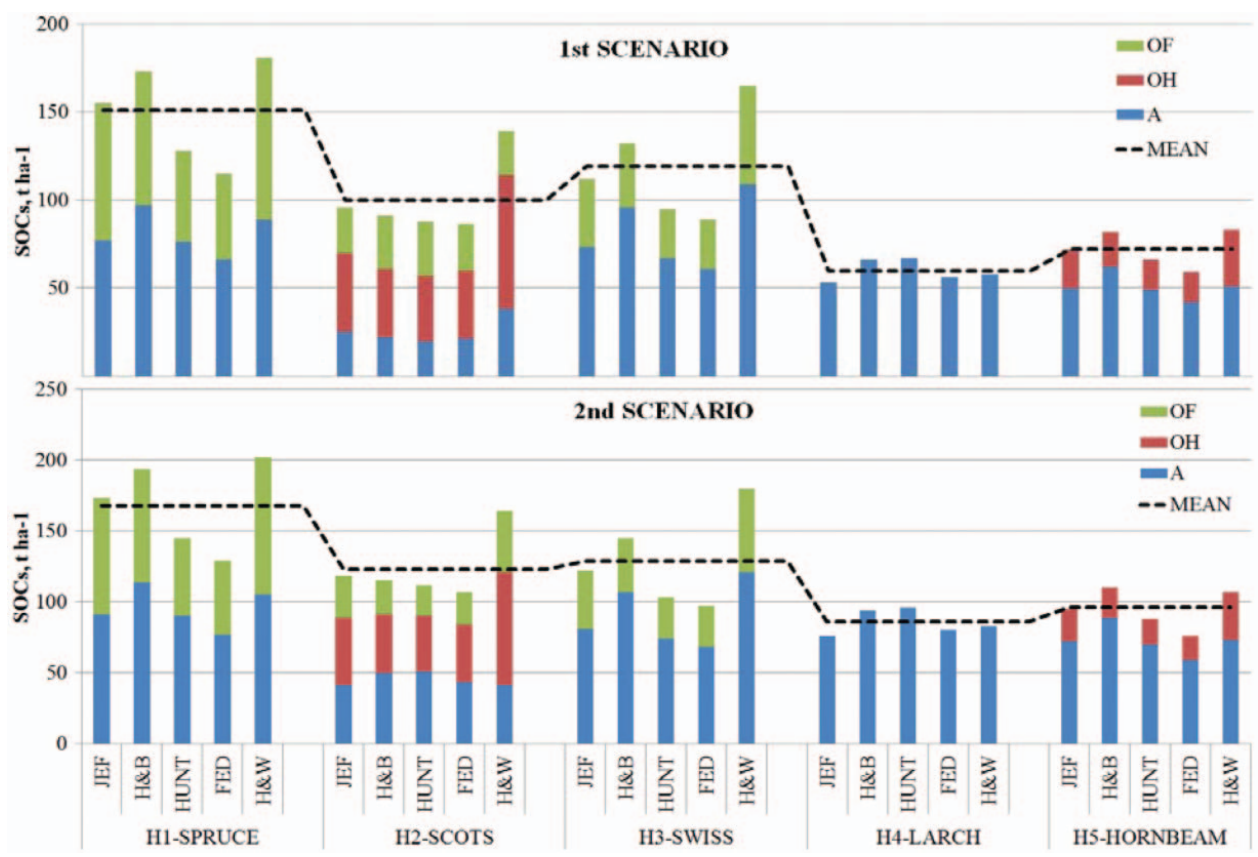

Figure 1 Calculation of the real SOC storage for the different forest stands including coarse material (top) and excluding it (bottom), with reference to five pedotransfer functions. The SOC contribution of various soil horizons at each site is shown (color figure available online).

the stocks calculated including, or excluding, the coarse fraction, the humus thickness is the main driving factor. However, it cannot be excluded that different humus forms might influence SOC storage as well.

In order to overcome the recorded differences in humus thickness, and to estimate the inherent potential of different humus forms to sequester carbon, we calculated the average OC (tons per hectare per $\mathrm{cm}$ ) stored at every site in a potential scenario (Figure 2), i.e. considering a soil thickness of $10 \mathrm{~cm}$ for each profile.

The potential scenario shows a different trend with respect to the real one. Yet, the potential carbon stock is greater under the Swiss Pine stand $\left(\mathrm{H} 3\right.$, average $\left.71 \mathrm{t} \mathrm{ha}^{-1}\right)$, than under the Spruce stand at site H1 (average $66 \mathrm{t} \mathrm{ha}^{-1}$ ), in comparison to the real scenario. Moreover, the differences between Amphimus forms at sites H2 (Swiss Pine) and H5 (Hornbeam) are strongly reduced in the potential scenario (Figure 2), indicating a similar storage capacity, although vegetation cover, climate, and altitude are quite different. Oligomull form under Larch (H4) shows less capacity to store carbon due to a faster process of OM decomposition (Zanella et al. 2001; Jabiol et al. 2007), which does not allow formation of thick organic horizons.

The potential scenario proposed in Figure 2 (bottom), where both total horizon thickness and coarse fraction are not considered, presents the same trend shown in the previous one (Figure 2, top). The recorded trend is consistent with what is supposed in the French humus classification (Zanella et al. 2001; Jabiol et al. 2007; Zanella et al. 2009), i.e., the poorly evolved and less active humus forms as Hemimoder and Dysmull, typical of high altitude and acidifying vegetation coverage (Swiss Pine and Spruce), have high storage capacity, since conifer litter holds components that are more difficult to decompose, resulting in litter accumulation at the forest floor and formation of acid compounds (Schulpet 


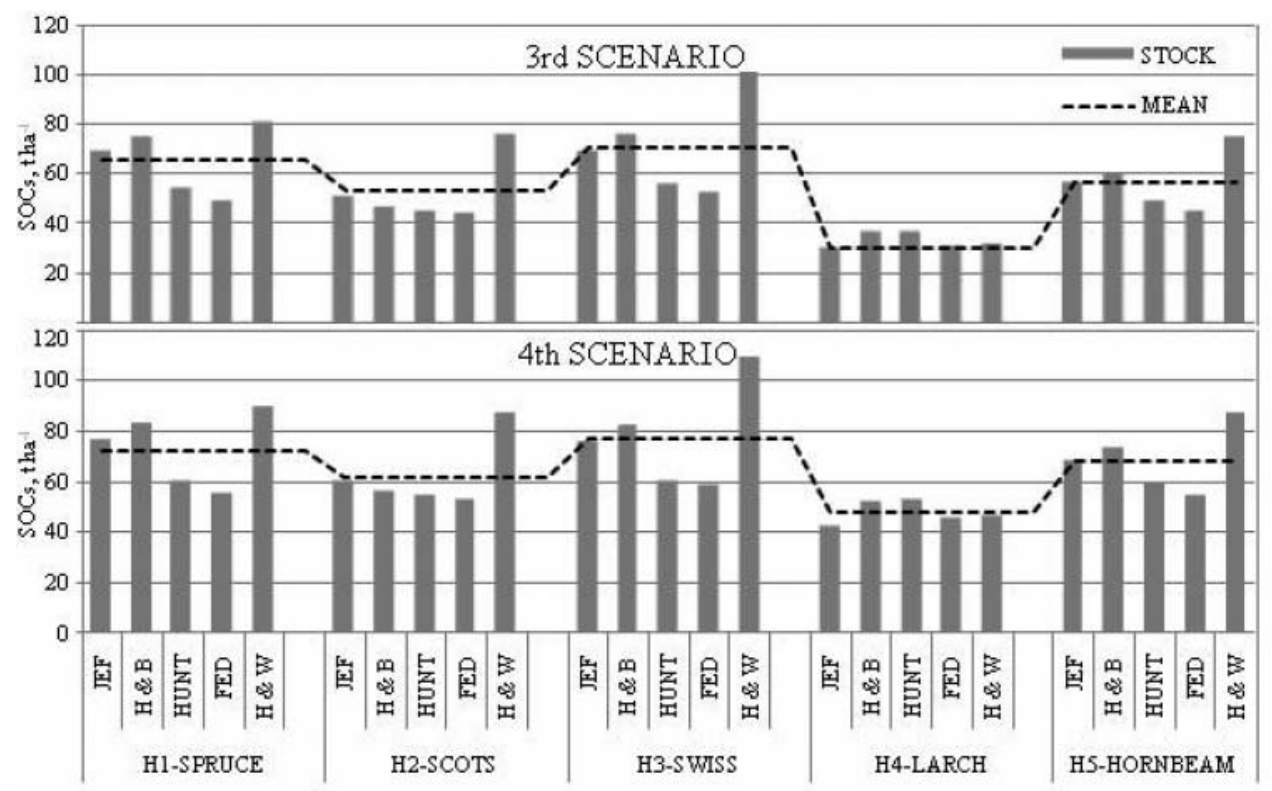

Figure 2 Estimate of the potential SOC storage in $10 \mathrm{~cm}$ soil for the different forest stands including coarse material (top) and excluding it (bottom), with reference to five pedotransfer functions.

al. 2008). According to the potential scenario, including the coarse material, in this study $71 \mathrm{t} \mathrm{ha}^{-1} \mathrm{C}$ have been found for Swiss Pine Hemimoder, while the humus forms with moderate evolution, such as Amphimus (Scots Pine and Hornbeam coverage, at sites 2 and 5 , respectively), store around $55 \mathrm{tha}^{-1}$, and the most evolved humus form as Oligomull (Larch stand at site 4 ), stores only 30 tha $^{-1}$. Therefore, with respect to the Hemimoder, a SOCs reduction of $22 \%$ and $57 \%$, respectively, was recorded in the last two humus forms, as a consequence of both lacking organic horizons and a faster mineralization process.

A positive correlation $(\mathrm{P}<0.05)$ between SOCs and altitude was observed (Figure 3 ), since at higher elevation there is a rise in the average thickness of the organic horizons, as well as an increase in carbon content, which is reflected in carbon stock increase. Both the graphs reported in Figure 3 present a tendency to increasing SOCs values with altitude, the real scenario (full line) showing higher values and more pronounced differences among the various sites, while the potential scenario (dotted line) shows more uniform values. The larch stand seems to be the most critical one in both the scenarios.

\section{DISCUSSION}

The average SOC storage of the five samples in the potential scenario is $55 \pm 16 \mathrm{t}$ $\mathrm{ha}^{-1} 10 \mathrm{~cm}^{-1}$, which is consistent with data reported in literature on calcareous soils of the Trentino Alps (Garlato et al. 2009a), where the SOCs average is $53.2 \mathrm{t} \mathrm{ha}^{-1} 10 \mathrm{~cm}^{-1}$. This result is quite far from the results found by Schulp et al. (2008) for O horizons of the Netherlands soils with conifers coverage (Scots Pine and Larch) and by Olsson et al. (2009) for O horizons of Swedish Podzols with forest coverage; in fact they found $27.57 \mathrm{tha}^{-1}$ and $28 \mathrm{t} \mathrm{ha}^{-1}$, respectively, on a soil thickness of about $8 \mathrm{~cm}$. On the other hand, Olsson et al. (2009) highlight also that in Norway forests in the same conditions the average SOCs is about $50 \mathrm{tha}^{-1}$, very close to the average value reported in this paper. 


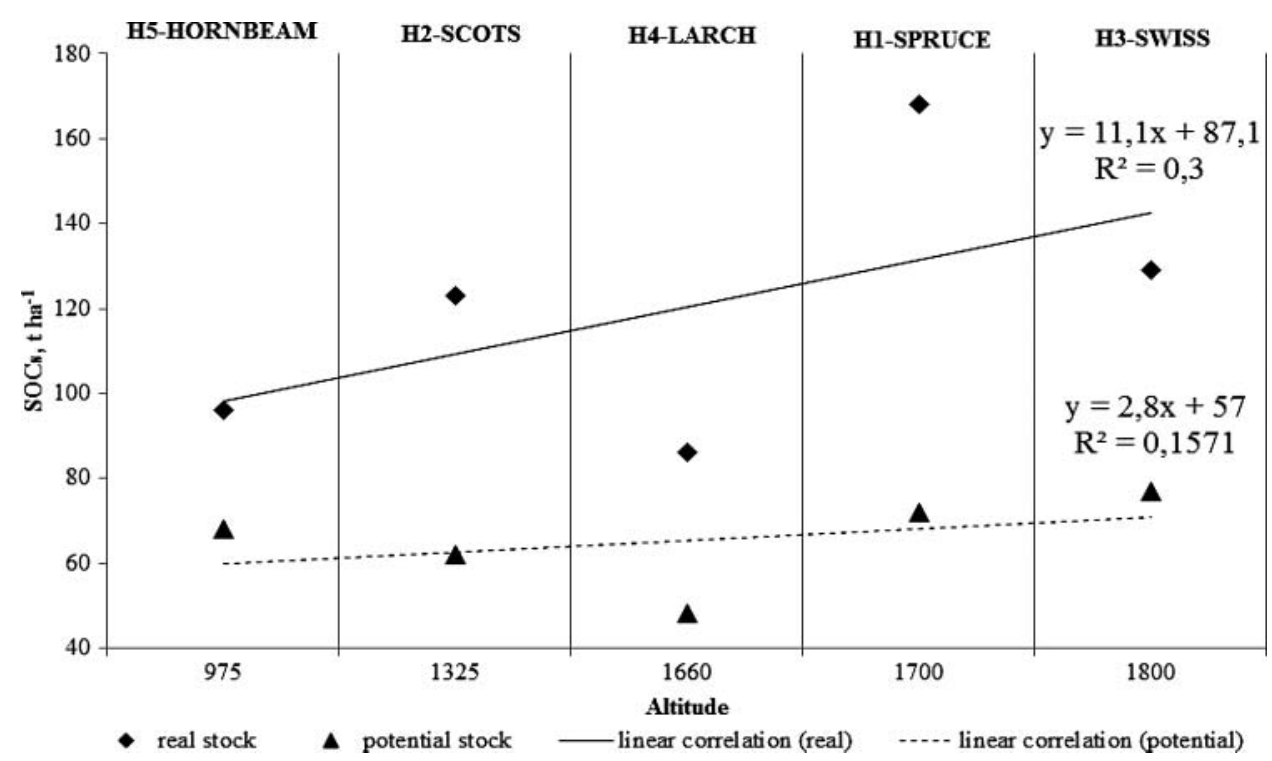

Figure 3 Regression analysis showing relationships between altitude (m a.s.l.) of the sites investigated and calculated real (full line) and potential (dotted line) carbon stocks $\left(\mathrm{t} \mathrm{ha}^{-1)}\right.$.

Data related to the 4th scenario (Figure 2, bottom) show that the presence of litter, especially if it is thick and slightly degraded, as that deriving from resinous plant remains, is a key factor for carbon sequestration; indeed, average SOC stored in forest soils is far in excess with respect to cultivated soils, steppes or grasslands, where the litter input is minimal (Cerli et al. 2009). In particular, conversion of forest to agricultural ecosystems invariably results in the depletion of SOC stock by 20-50\% (Lal 2005), as it is demonstrated by several studies (Oorts et al. 2007; Schulp et al. 2008; Olsson et al. 2009; Wang et al. 2009; Kaiser et al. 2011; Powlson et al. 2011).

In the cited papers, SOCs estimate is lower than those calculated for forest soils, irrespective of the soil thickness, suggesting litter originated by forest cover to be more effective in C storage (Lagagnière et al. 2010).

Forest soils too show some variability in SOC storage. In fact, the SOCs average values recorded in this study differ from those reported by Solaro and Brenna (2005) for the soils of Central Alps $\left(87 \mathrm{t} \mathrm{ha}^{-1} 30 \mathrm{~cm}^{-1}\right.$ ), as well as those reported by Petrella and Piazzi (2005) for Western Alps $\left(91 \mathrm{t} \mathrm{ha}^{-1} 30 \mathrm{~cm}^{-1}\right.$ ). Therefore, a decrease of SOCs is evident following a W-E transect along the Alps, and this is consistent with studies carried out by Fantappiè, L'Abate, and Costantini (2010).

Climate has a fundamental effect on soil properties and processes, and may influence carbon sequestration/release in forest soils. For instance, Melillo et al. (2002) observed that soil warming accelerated the mineralization process of $\mathrm{OC}$ and $\mathrm{CO}_{2}$ fluxes to the atmosphere. Yet, an increase in global temperature may result in a long-term loss of the SOC stock, converting forests to carbon sources and triggering a positive feedback between $\mathrm{CO}_{2}$ emissions and global warming (Lal 2005; Pilli 2006; Tedeschi 2007).

Organic horizons with relatively short turnover rate are particularly vulnerable to climate change or other disturbances, as change in soil use and management (Schulze et al. 2009).The driving forces that control the humus decomposition rate are litter type and climate. Climate is the dominant factor in areas subject to extreme weather conditions, as 
in mountain regions. In particular, OM mineralization rate is directly related to potential evapotranspiration (PET) and temperature (Coûteaux et al. 1995; Lal 2005). Yet, the sites at higher altitude (H1-Spruce, H3-Swiss), where PET and mean annual temperature (maT) have the smallest values, present less active forms of humus, which accumulate thick organic layers and great amounts of SOC, while at site H4 (Larch stand), where PET and maT increase, mineralization rate also increases, as reported by Calabrese et al. (1996) and Zanella et al. (2001).

Climate as single driving force, however, cannot explain the peculiarity of Amphimus forms, which is typical of a transitional ecosystem that has not yet attained the steady state (Chersich et al. 2007).

At lower altitude (sites $\mathrm{H} 2$ and H5), with mitigation of climate conditions, an increased importance of litter and substrate as driving forces is recorded. Indeed, at site $\mathrm{H} 2$ the forest floor is composed of organic residues associated with high contents of lignin, resins, and waxes, and low nitrogen content (Zanella et al. 2001; Lal 2005), that make them unattractive to soil microorganisms. The forest floor at site H5 should have enhanced mineralization processes, and improved soil fertility; unlikely, the humus form (Amphimus) is poorly active; it is likely that the calcareous parent material blocks the "secondary mineralization" of the litter (Zanella et al. 2001), slowing the OM decomposition.

\section{CONCLUSIONS}

Carbon sequestration in the top layer of forest soils in Alpine environment would result from the influence of interacting factors such as humus type and climate. A clear correlation is established between the humus forms and SOCs. The most evolved humus (Oligomull) presents the lowest values of SOCs, and the little evolved forms (Hemimoder and Dysmull), the highest values.

The main driving factor for SOC storage is climate, which controls the thickness of the organic horizons and the OM decomposition rate. Evidence is given by the positive correlation between SOCs and altitude. However, current knowledge about the SOM dynamics (humification rate, mineralization, stabilization) is still limited.

The variability of the recorded SOCs values demonstrates the criticism represented by the BD estimate by PTFs, since it is affected by under- or over-estimation. Yet, the assessment of SOCs data highlights net relationships between humus forms and potential SOCs, but it is not possible to quantify with certainty the actual difference in storage capability of each humus form. Future studies on SOC storage should use pedotransfer functions calibrated on a local dataset of BD in order to minimize this concern.

\section{ACKNOWLEDGMENTS}

We are very grateful to the editor and to the two anonymous reviewers for their valuable suggestions and comments that contributed to improve the quality of this work.

\section{REFERENCES}

AFES. 2009. Référentiel Pèdologique 2008. In: Baize D, Girard CM, editors. Paris (FR): Quae Press. p. 432.

Andreetta A, Ciampalini R, Moretti P, Vingiani S, Poggio G, Matteucci G, Tescari F, Carnicelli S. 2011. Forest humus forms as potential indicators of soil carbon storage in Mediterranean environments. Biol Fert Soils 47:31-40. 
Andreis C, Armiraglio S, Cerabolini B, Gandellini F, Gandini P. 2003. Calcolo informatizzato del bilancio idrico del suolo. Natura Bresciana, Ann Mus Civ Sci Nat 33:209-216.

ARPAV. 2006. Validazione della metodologia AFRSS in Regione Veneto. Conference proceedings at Ispra, Italy 21-23 November 2006.

Banfield GE, Bhatti JS, Jiang H, Apps MJ. 2002. Variability in regional scale estimates of carbon stocks in boreal forest ecosystems: results from West-Central Alberta. Forest Ecol Manag 169:15-27.

Batjes NH. 1996. Total Carbon and Nitrogen in the soils of the world. Eur J Soil Sci 47:151-163.

Bosellini A. 1996. Geologia delle Dolomiti. Bolzano (IT): Athesia Press, p. 192.

Calabrese MS, Nicolini G, Sartori G, Zanella A. 1996. Gli humus forestali delle faggete e abietifaggete del trentino: metodologia d'indagine e risultati preliminari. Bollettino SISS 8:35-49.

Cerli C, Celi L, Bosio P, Motta R, Grassi G. 2009. Effect of land use change on soil properties and carbon accumulation in the Ticino Park (North Italy). Studi Trent Sci Nat 85:83-92.

Chersich S, Galvan P, Frizzera L, Scattolin L. 2007. Variabilità delle forme di humus in due siti campione di pecceta altimontana trentina. Forest 4:220-226.

Corti G, Ugolini FC, Agnelli A, Certini G, Cuniglio R, Berna F, Fernández Sanjurjo MJ. 2002. The soil skeleton, a forgotten pool of carbon and nitrogen in soil. Eur J Soil Sci 53:283-298.

Coûteaux MM, Bottner P, Björn B. 1995. Litter decomposition, climate and litter quality. Trends in Ecol \& Evol 10:63-66.

Del Favero R, Lasen C. 1993. La vegetazione forestale del Veneto. 2nd ed. Padova (IT): Progetto Editore Press, p. 313.

De Vos B, Deckers J, Muys B, Quataert P, Van Meirvenne M. 2005. Predictive quality of pedotransfer functions for estimating BD of forest soils. Soil Sci Soc Am J 69:500-510.

DM 13/09/1999. Metodi ufficiali di analisi chimica del suolo. Gazz. Uff. Rep. Ital., Suppl. no. 387 Ordin. $n^{\circ} 248$ del 21/10/1999.

Dixon RK, Brown S, Houghton RA, Solomon AM, Trexler MC, Wisniewski J. 1994. Carbon pools and flux of global forest ecosystems. Science 263:185-190.

Don A, Schumacher J, Scherer-Lorenzen M, Scholten T, Schulze ED. 2007. Spatial and vertical variation of soil carbon at two grassland sites-implications for measuring soil carbon stocks. Geoderma 141:272-282.

Dou S, Zhang J, Li K. 2008. Effect of organic matter applications on 13 C-NMR spectra of humic acids of soil. Eur J Soil Sci 59:532-539.

Fantappiè M, Costantini EA, Labate G. 2010. Factors influencing Soil Organic Carbon stock Variations in Italy during the Last Three Decades. In: Zdruli M, Pagliai S, Kapur A, Fiz C, editors. Land degradation and desertification: assessment, mitigation and remediation. Berlin: Springer. p. 435-465.

Galbraith JM, Kleinman JA, Bryant RB. 2003. Sources of uncertainty affecting soil organic carbon estimates in northern New York. Soil Sc Am J 67:1206-1212.

Garlato A, Obber S, Vinci I, Mancabelli A, Parisi A, Sartori G. 2009a. La determinazione dello stock di carbonio nei suoli del Trentino a partire dalla banca dati della carta dei suoli alla scala 1:250.000. Studi Trent Sci Nat 85:157-160.

Garlato A, Obber S, Vinci I, Sartori G, Manni G. 2009b. Stock attuale di carbonio nei suoli di montagna del Veneto. Studi Trent Sci Nat 85:69-81.

Goidts E, Crucifix M, Van Wesemael B. 2009. Magnitude and sources of uncertainties in soil organic carbon (SOC) stock assessments at various scales. Eur J Soil Sci 60:723-739.

Green RN, Trowbridge RL, Klinka K. 1993. Towards a Taxonomic classification of humus forms. Forest Science, Monograph 29:1-48.

Grüneberg E, Schöning I, Kalko EKV, Weisser WW. 2010. Regional organic carbon stock variability: A comparison between depth increments and soil horizons. Geoderma 155:426-433.

Hedde M, Aubert M, Decaens T, Bareaui F. 2007. Dynamic of soil carbon in a beechwood chronosequence forest. For Ecol Manag 255:193-202.

Hollis JM, Woods SM. 1989. The measurement and estimation of saturated soil hydraulic conductivity. SSLRC Research Report, Cranfield University, Silsoe Campus, UK: 19 (unpublished). 
IPCC (Intergovernmental Panel on Climate Change). 2001. Climate change 2001: The scientific basis. 3rd assessment report. Cambride (UK): Cambridge University Press.

Jabiol B, Brethes A, Brun J, Ponge J, Ponge F, Toutain F. 2007. L'humus: sous toutes ses formes. 2nd ed. Nancy (FR): Agro Paris Tech Engref Press, p. 63.

Kaiser M, Walter K, Ellerbrock RH, Sommer M. 2011. Effects of land use and mineral characteristics on the organic carbon content, and the amount and composition of Na-pyrophosphate-soluble organic matter, in subsurface soils. Eur J Soil Sci. 62:226-236.

Kulmatiski A, Vogt DJ, Siccama TG, Tilley JP, Kolesinskas K, Wickwire TW, Larson BC. 2004. Landscape determinants of soil carbon and nitrogen storage in southern New England. Soil Sci Soc Am J 68:2014-2022.

Lagagnière J, Angers DA, Paré D. 2010. Carbon accumulation in agricultural soils after afforestation: a meta-analysis. Global Change Biol 16:439-453.

Lal R. 2005. Forest soils and carbon sequestration. For Ecol Manage 220:242-258.

Lal R. 2009. Challenges and opportunities in soil organic matter research. Eur J Soil Sci 60:158-169.

Llorente M, Glaser B, Turrión MB. 2010. Storage of organic carbon and Black carbon in density fractions of calcareous soils under different land uses. Geoderma 159:31-38.

Lopez R, Gondar D, Iglesias A, Fiol S, Antelo J, Arce F. 2008. Acid properties of fulvic and humic acids isolated from two acid forest soils under different vegetation cover and soil depth. Eur $\mathbf{J}$ Soil Sci 59:892-899.

Melillo JM, Steudler PA, Aber JD, Newkirk K, Lux H, Bowles FP, Catricala C, Magill A, Ahrens T, Morrisseau S. 2002. Soil warming and carbon-cycle feedbacks to the climate system. Sci 298:2173-2176.

Mikhailova EA, Post CJ, Lal R. 2009. Organic carbon stocks in the Russian Chernozem. European Journal of Soil Science 57:330-336.

Mou P, Jones RH, Guo DL, Lister A. 2005. Regeneration strategies, disturbance and plant interactions as organizers of vegetation spatial patterns in a pine forest. Lands Ecol 20:971-987.

Olsson MT, Erlandsson M, Lundin L, Nilsson T, Nilsson Å, Stendahl J. 2009. Organic Carbon stocks in Swedish Podzol soils in relation to soil hydrology and other site characteristics. Silva Fennica 43(2):209-222.

Oorts K, Bossuyt H, Labreuche J, Merckx R, Nicolardot B. 2007. Carbon and nitrogen stocks in relation to organic matter fractions, aggregation and pore size distribution in no-tillage and conventional tillage in northern France. Eur J Soil Sci 58:248-259.

Penne C, Ahrends B, Deurer M, Böttcher J. 2010. The impact of the canopy structure on the spatial variability in forest floor carbon stocks. Geoderma 158:282-297.

Perruchoud T, Walthert L, Zimmermann S, Luscher P. 2000. Contemporary carbon stocks of mineral forest soils in the Swiss Alps. Biogeochemistry 50:111-136.

Petrella F, Piazzi M. 2005. Il carbonio organico negli ecosistemi agrari e forestali del Piemonte: misure ed elaborazioni (Organic carbon in the agricultural and forest ecosystems of Piedmont Region: measures and elaboration). Bollettino AIP, n.1-3.

Piccolo A. 1996. Humus and soil conservation. In: Piccolo A, editor. Humic substances in terrestrial ecosystems. Amsterdam (NED): Elsevier Press. p. 225-264.

Pignatti S. 1981. Carta dei complessi di vegetazione di Cortina D'Ampezzo 1:50.000 (Forest vegetation map of Cortina D' Ampezzo 1: SQ.000). Roma: P.F. Promotion of environment quality, C.N.R.p. 1-39.

Pilli R, Anfodillo T, Dalla Valle E. 2006. Stima del carbonio in Foresta: metodologie ed aspetti normativi (Forest carbon estimate: methods and regulatory aspects). Proceeding of the 42nd annual Ecology course; Padova (IT). p. 189.

Powlson DS, Whitmore AP, Goulding KWT. 2011. Soil carbon sequestration to mitigate climate change: a critical re-examination to identify the true and the false. Eur J Soil Sci 62:42-55.

Prichard SJ, Peterson DL, Hammer RD. 2000. Carbon distribution in subalpine forests and meadows of the Olympic Mountains, Washington. Soil Sci Soc Am J 64:1834-1845.

Schnitzer M. 1986. Binding of humic substances by soil mineral colloids. In: Schnitzer M, editor. Interactions of soil minerals with natural organics and microbes. Madison (WI): Madison Press. p. 77-101. 
Schöning I, Totsche KU, Kögel-Knabner I. 2006. Small scale spatial variability of organic carbon stocks in litter and solum of a forested Luvisol. Geoderma 136:631-642.

Schulp CJE, Nabuurs G, Verburg PH, de Waal RW. 2008. Effect of tree species on carbon stocks in forest floor and mineral soil and implications for soil carbon inventories. For Ecol Manage 256:482-490.

Schulze K, Borken W, Muhr J, Matzner E. 2009. Stock, turnover time and accumulation of organic matter in bulk and density fractions of a Podzol soil. Eur J Soil Sci 60:567-577.

Schwager SJ, Mikhailova EA. 2002. Estimating variability in soil organic carbon storage using the method of statistical differentials. Soil Sci 167:194-200.

Smith OH, Peterson GW, Needelman BA. 2000. Environmental indicators of agroecosystems. Adv Agron 69:75-97.

Solaro S, Brenna S. 2005. Il carbonio organico nei suoli e nelle foreste della Lombardia (Organic carbon in soils and forests of Lombardy Region). Bollettino AIP. n.1-3.

Somaratne S, Seneviratne G, Coomaraswamy U. 2005. Prediction of soil organic carbon across different land-use patterns: a neural network approach. Soil Sci Soc of Am J 69:1580-1589.

Spielvogel S, Prietzel J, Auerswald K, Kögel-Knabner I. 2009. Site-specific spatial patterns of soil organic carbon stocks in different landscape units of a high-elevation forest including a site with forest dieback. Geoderma 152:218-230.

Springer U, Klee J. 1954. Prufung der Leistungfahigkeit von einigen wichtigen verfaren zur Bestimmung des Kohlenstoffe mittels Chromschwefelsaure sowie Vorschlag einer neuen Schnellmethode. Z. Pflanzener. Bodenk 64:1-26.

Stevenson FJ. 1994. Humus chemistry: genesis, composition, reactions. 2nd ed. New York: Wiley and Sons Press, p. 496.

Tedeschi V. 2007. Nuove indicazioni sui processi che controllano la capacità di accumulo di carbonio nel suolo. Forest 4(4):348-350.

USDA. 2010. Key to soil taxonomy, 11th ed. Pocahontas, Blacksburg-Virginia (USA): USDA.

Venteris ER, McCarthy GW, Ritchie JC, Gish T. 2004. Influence of management history and landscape variables on soil organic carbon and soil redistribution. Soil Science 169:787-795.

von Lützow M, Kögel-Knabner I, Ekschmitt K, Matzner E, Guggenberger G, Marschner B, Flessa H. 2006. Stabilization of organic matter in temperate soils: Mechanisms and their relevance under different soil conditions-a review. Eur J of Soil Sci 57:426-445.

von Lützow M, Kögel-Knabner I, Ludwig B, Matzner E, Flessa H, Ekschmitt K, Guggenberger G, Marschner B, Kalbitz K. 2008. Stabilization mechanisms of organic matter in four temperate soils: development and application of a conceptual model. Zeit. Pflanz. Bodenk 171:111-124.

Zanella A, De Siena C, Frizzera L, Jabiol B, Nicolini G, Tomasi M. 2001. Humus forestali. Trento (IT): Centro di Ecologia Alpina-Trento Press, p. 320.

Zanella A, Jabiol B, Ponge J, Sartori G, De Waal R, Van Delft B, Graefe U, Cools N, Katzensteiner K, Hager H, English M, Brethes A. 2009. Toward a European humus forms reference base. Studi Trent Sci Nat 85:145-151.

Zilioli D. 2007. Carta dei suoli del territorio comunale di Cortina D'Ampezzo 1:50.000. U of Venice (unpublished).

Zilioli D, Bini C. 2009. Dieci anni di ricerche pedologiche in ambiente alpino: considerazioni sulla distribuzione e sull'evoluzione dei suoli nella regione dolomitica. Studi Trent Sci Nat 85:61-68.

Zimmermann M, Leifeld J, Schmidt MWI, Smith P, Fuhrer J. 2007. Measured soil organic matter fractions can be related to pools in the Roth C model. Eur J Soil Sci 58:658-667.

Wang Q, Zhang L, Li L, Bai Y, Cao J, Han X. 2009. Changes in carbon and nitrogen of Chernozem soil along a cultivation chronosequence in a semi-arid grassland. Eur J Soil Sci 60:916-923.

Wuddivira MN, Camps-Roach G. 2007. Effects of organic matter and calcium on soil structural stability. Eur J Soil Sci 58:722-727. 